\title{
The Rhetoric of "Bragoro": The Philosophy Behind Akan Traditional Concept of Marriage
}

\author{
Peter Arthur 1 (D) Angelina Mensah \\ 1 Department of English, Faculty of Social Sciences, Kwame Nkrumah University of Science and Technology, Kumasi, Ghana.
}

\begin{abstract}
This paper discusses the intertextual relationship between the world of Akan Bragoro (puberty rites) song texts and the real world of Akans. The Akan Bragoro song texts are performed during Bragoro celebrations and the song texts define the Akan concept of sex and marriage within the parameters of traditional Akan philosophy. The paper uses qualitative research methods that are irrigated by ethnographic and stylistics approaches to text interpretation. The findings of the research indicate that texts of Akan Bragoro songs key all the meanings this traditional philosophy has to offer: sex is strictly a marital affair and marriage is for those who are prepared for it. The stylistics of the song texts also frame the epistemic of Akan love and that the basic condition of Akan conjugal love is a good character on the side of both the man and the woman. The paper further reveals that the Akan Bragoro song texts constitute the site where the precipitates of Akan marriage are provided and Bragoro initiates are introduced to the Akan way of life. These precipitates are rehearsed in performance year after year, making the Akan Bragoro an enduring cultural practice that guides the life of the Akans throughout all ages.
\end{abstract}

Correspondence:

Peter Arthur

Email: pitah_7@yahoo.com

Manuscript

Received 27th July, 2021

Accepted 15th September, 2021,

Published online 20th September,

2021.

Keywords: Performance, Bragoro song texts, Verbal art, Cognitive poetics, Tradition

(c) 2021 The Author. Published and Maintained by Noyam Publishers.

This is an open access article under the CCBY license (http://creativecommons.org/licenses/by/4.0/).

\section{INTRODUCTION}

In times past, literature as a branch of study had nothing to do with orality. The reason was partly the substantive meaning of literature being a thing of writing and by extension reading, ${ }^{1}$ It took a lot of intellectual investment to break down the walls that divided them thanks to the hard work of intellectuals who committed their energy not only to language as arbitrary, a system, vocalic, social, creative but also as a convention and more importantly as a means of communication. ${ }^{2}$ Pioneers like de Saussure, Sanders Pierce and Levi-Strauss have done their best to look at the symbolic and the creative nature of language and thanks to intellectuals like Dell Hymes, John Gumpez and other linguists, it has become very apparent that culture is the supporting system for the symbolic and creative nature of language. The meaning of the text in the past, therefore, moved from what was only written but today it could be anything that has an interpretable sign. Hymes and Gumpez ${ }^{3}$ have

\footnotetext{
Jacques Goody. The Interface between Written and Oral,( London: CUP,1987).

2 Ralph Fasold and Jeff Connor-Clinton, eds. Introduction to Language and Linguistics, (New York: CUP, 2006).

3 John Gumpez, The Sociolinguistic Significance of Conversational Code-Switching Regional Language Centre (RELC), Vol. 8, Issue 2, 1-37; Dell Hymes, and John J. Gumperz,. Direction in Sociolinguistics: Ethnography in Communication, (London:

Bolt, Rinehart and Winston Inc, 1972).
} 
been pioneers in the ethnography of communication but the credit of making verbal art, the study committed to poetics or the stylistic analysis of oral expression, accepted in the area of literary studies goes to Bauman. ${ }^{4}$ The question confronted by this paper is whether these songs as elements of language still carry symbolic meanings in the form of values and ethics worthy of emulation by the modern Ghanaian youth. In this light, the paper interrogates whether the songs of Bragoro celebrations express the Akan philosophy of marriage and to what extent do these songs serve as "handbooks" for a good marriage. By Akan philosophy, what is being referred to is an aspect of African philosophy, "a collective system of thought, common to all Africans or at least to all members, past, present and future, of such and such an African ethnic group"5 or existing knowledge that belongs to Africans. ${ }^{6}$ The paper investigates all these questions by looking at the discourse of the songs in relation to their cultural textuality and their cognitive poetics, that is, meaning from the point of view of the reader or listener.

\section{LITERARY VIEWS ON VERBAL ART, CULTURE AND TRADITIONS}

The study of verbal art, previously taught to belong to the oral culture and lacking in scholarly merit, now provides a huge window to investigate culture, not just as a sociological and even as an anthropological phenomenon but as a historical and literary phenomenon. It is now a space from which the culture of the people can be read and this includes the history and the uniqueness of art inherent in a particular culture, courtesy of its language. One interesting aspect about verbal art is that it is synonymous with "tradition", which is passed on from generation to generation by way of belief and customs by a group of people mainly through orality rather than through the written. By this definition, the study is not about religious tradition which talks about the dogma that is not supported by any writing but believed to come from God. However, it must be pointed out here, that the concept of "tradition" is not a foregone conclusion in the sense provided by Ong; it has been subjected to a lot of debate. That means that there is still not a razor-sharp definition but by and large, there is a very practical definition and that is what has been adopted by this paper. Pascal Boyer defines "tradition" as cultural phenomenon in three categories: (i) they are instances of social interaction, (ii) they are repeated; and (iii) they are psychologically salient. ${ }^{7}$ Boyer's definition of (i) and (ii) are the very core of this discussion and so the relevance of (iii) can be looked at before (i) and (ii). Boyer postulates that every performer of verbal art first has something in mind before he performs it and to him, this appears as a psychological process that needs analysis in psychology. Nevertheless, according to him, "the technicalities of cognition, the workings of the black box, do not really matter; what counts is the alleged result, namely the 'conservation' of certain concepts and beliefs." By this explanation, therefore, Boyer dismisses the idea that the concept "tradition" is the preserve of psychology and contextualizes it in the study of verbal art or cultural studies.

With regard to (i) and (ii), Boyer thus sums up the definition of "tradition" as "things people actually do and ethnographers observe, not the things anthropologists think should be posited in order to explain what people do." 8 The concept of "tradition" in this paper is therefore what the people do and how they arrive at what they do and this goes in consonance with Boyer's thinking which equates "events" to "traditional" and this is to do away with all the complications that come along with the usual anthropological confusion of what "tradition" is. The event is therefore considered to be a social interaction which in this context has performers and audience who operate by using a cultural genre which has its own template to be followed or which is used to key the performance. ${ }^{9}$ People repeat events because these events which become rituals express ideas." ${ }^{10}$ The premium here is those past ideas that are beneficial to the survival of the people are repeated. It is about power. It is social organization, cohesion and peace. These ideas were not chanced upon as implied

\footnotetext{
4 Richard Bauman, Verbal Art as Performance, ( Illinois: Waveland Press, 1977).

5 Pauline. Hountondji,transl. H. Evans \& J. Rée, African Philosophy: Myth and Reality, (Bloomington, Indiana: Indiana University Press, 1983), 55-56.

6 Kwesi Wiredu, Philosophy and an African Culture, (Cambridge, Cambridge University Press, 1980).

7 Pascal Boyer, Tradition as Truth and Communication: A cognitive description of traditional discourse, (New York: Cambridge University Press, 1994).

8 Boyer, Tradition as Truth and Communication.

9 Bauman, Verbal Art as Performance.

10 Boyer, Tradition as Truth and Communication: 10
} 
by Shils. Shils' postulations obscure the utilitarian factor of such ideas; how they help the society to maintain social control and its accompanying peace. Festivals in oral communities, therefore, serve as a site where the initiated are introduced to the way of life of the community. ${ }^{11}$

Perhaps of particular interest to literary studies of such festivals, considered events for the purpose of this analysis, are the characters involved. Festivals are events which involve places, time, characters and actions, the tools any narratologist would be very happy to work with. These festivals, unlike ordinary narratives, are acted by people, in a particular time frame, in a particular place, following specific activities. Admittedly, there is a lot of literature on the sociological and the anthropological treatment of African festivals but very little is known about the literary investigation of these festivals. This paper aims at filling this lacuna by looking at the poetics of the songs of Bragoro of the people of Worakese in the Ashanti Region of Ghana.

\section{METHODOLOGY}

The paper has recourse to the qualitative research approach which has the potential of not only observing what the people of Worakese do but also how they think about what they do. Bragoro has excited the researchers for some time now so when it was announced on the radio that the people of Worakese were going to celebrate Bragoro in 2019, the researchers took the opportunity to go and see the Queen Mother of Worakese in preparation for a participant observation research approach. One of the researchers who hails from the vicinity of Worakese went to the Queen Mother who mentally prepared her for the festival by taking her through all the activities and their significance, even before the festival got underway. This was a very powerful preparation for a participant observation research exercise. The festival started on $21^{\text {st }}$ February and lasted for four days and the researchers were present before the festival started. They interacted with the citizens by hanging out with them, engaging them in conversations concerning the upcoming event and interviewed them as well. During the events of the festival, while the researcher who had been "initiated" into the rites was fully involved in the celebration, the other researcher and his assistants were busing taking notes and pictures, videoing the goings-on of the event and interviewing people. The people who were interviewed were supposed to be a section from the ruling elite of the town, the elders of both the male and female population and the youthful males and females of the town, especially the initiates of Bragoro. After each day of the celebration, the researchers met and reviewed their data and made sure the data was properly harmonized and that the data represented the actual happenings of the events, paying particular attention to the researcher participant and how she felt participating in the event. All the audio recordings were transcribed and translated into English using the literal translation approach. Even after the festival, the researchers made phone calls and visits to people who needed to be contacted for clarifications. The data was subjected to a stylistic approach of analysis and the theoretical framework rested on the Performance theory of Richard Bauman.

\section{DISCUSSION}

\section{The People of Worakese}

Worakese is a village in the Bosomtwe District in the Ashanti region of Ghana. It is one of the twenty-one villages close to Lake Bosomtwe and their main occupation is farming. They are Akans. The Akans occupy the southern and the middle portion of Ghana. They belong to the Kwa group of languages in West Africa and Ghana. ${ }^{12}$ They constitute about $47 \%$ of the entire population in Ghana. ${ }^{13}$ Indeed, the Bragoro celebration is performed by all Akans even though the influence of modernity has made most Akan communities either water down the importance of or the celebration of the rites. In fact, for the larger part of Akan communities, Bragoro is only in name. Worakese happens to be one of the very few Akan communities to re-enact the ageold Bragoro.

\section{Akan Bragoro}

The Akans cherish the morality of the woman and for them, they believe that this starts with the young girl. To them, morality is discipline and discipline is the way of the community, a necessity that brings about social

${ }^{11}$ Edward Shils, Tradition, (Chicago, University of Chicago Press, 1981).

12 The same group is found in Ivory Coast where they constitute about half of the country's population.

${ }_{13}$ Ghana Statistical Service, "Ghana Facts Sheet," 2021. Accessed, August 8, 2021. www.statsghana.gov.gh/ghfactsheet.php. 
cohesion. To this end, the discipline of the young girl is epitomized in her virginity and virginity among the Akans is such a cherished phenomenon that there is a time on the Akan calendar set aside for its celebration and they call it Bragoro. It is very elaborate and can take as long as one week. In Worakese, when a girl menstruates, the mother reports to the Queenmother. The Queenmother makes a list of such girls and during the last week of January or the first week in February, the festival is celebrated. At the dawn of the Saturday of the scheduled time, the old ladies go round the village in jubilation, singing, dancing and heralding the arrival of the festival. All the girls on the Queenmother's list meet in the Bragoro Hemaa's (Queen of Bragro) ${ }^{14}$ house and they are introduced to the Chief of the village. On the next day, they are dressed in a special costume and taken to the riverside for a ritual bath: their cloth is wrapped around their waist and another is wrapped around the bust covering the breasts. In fact, in the olden days, the breasts were supposed to be on exhibition because it was taught to be the center of feminine attraction but currently, for the sake of modernity, the breast is covered. The next afternoon which is a Sunday, they are given cto (a ceremonial meal made from yam signifying the vicissitudes in marriage.

It must be pointed out that Bragoro is not marriage but every activity in it is a rehearsal for marriage so even though this article discusses Bragoro, alluding and sometimes equating Bragoro to marriage should be expected. After the ceremonial eating of cto, all the initiates congregate in the village foyer for the dignitaries in the village to give them motivational speeches. The remarkable aspect of all these activities is the singing of Bragoro songs which to all intents and purposes, are supposed to inform and form the mind of the soonto-be wife to be a good wife. The songs spell out all the conditions needed for a good Akan marriage. In other words, the songs mark the separation from spinsterhood and a transition to married life. ${ }^{15}$ This paper subsequently looks at the various themes that underlie the celebration of Bragoro.

(i) What to look for in a man in Akan marriage

(ii) The role of the woman in Akan marriage

(iii) The Akan cultural definition of love

\section{What to look for in a man in Akan marriage}

On the second day of the celebration, during the ceremonial meal of the sto, the women in the gathering, sang to the rhythm of nnwonkro music, played by men and women but sang only by women. At the climax of this session, the atmosphere was charged and the women singers were heard singing:

\section{Amma Serwaah}

Amma Serwaah ee, Amma Serwaah! Amma Serwaah ee, Amma Serwaah!

Amma Serwaah ee, Amma Serwaah

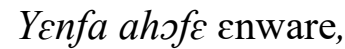

Yede suban na eware.

Amma Serwaah ee, Amma Serwaah!

Amma Serwaah ee, Amma Serwaah!

Amma Serwaah ee, Amma Serwaah

We don't marry because of looks,

We do marry because of good character

Amma Serwaah ee, Amma Serwaah!

Amma Serwaah ee, Amma Serwaah!

Yenfa sika enware,

Yede do na eware.

We don't marry because of money,

We marry out of love.

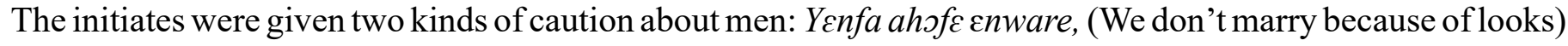

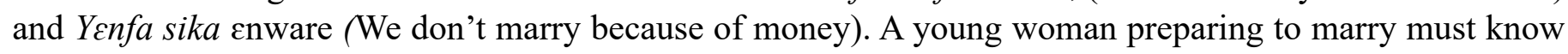
what makes a partner a good husband. The stage of the puberty ritual for the young woman is very significant considering the fact that it marks the separation from spinsterhood to the transitional period to married life. The initiates are cautioned that not all that glitters is gold. The lesson is simple: good looks and riches do not make good husbands. This message is even more significant in contemporary times when materialism and financial considerations constitute a huge consideration in accepting the hands of men in marriage in Ghana. Today, some Ghanaian women are so engrossed in materialism and are only interested in money. This trend

\footnotetext{
14 This is one of the oldest women in the society who is in charge of all the rituals.

15 Joseph Campbell, The Hero with Thousand Faces. (California: Joseph Campbell Foundation, 2008).
} 
has led to these women being referred to as slay queens in Ghanaian social media circles. Ghanaian movies and songs depicting contemporary lifestyles in Ghana are awash with images suggesting the high premium some Ghanaian women place on the role money plays in marriage. Such financial considerations can bring dire social problems and in a quantitative study by Ahonsi et al, ${ }^{16}$ they discovered that $20.68 \%$ of Ghanaian young girls, mostly the nonliterate, married at very young ages. The researchers attributed this phenomenon to financial insecurity on the part of these teenage girls. It is for the purpose of fighting such creeping unsavory culture that Bragoro is celebrated to train girls to make better choices.

The text also warns initiates not to substitute good looks for a good husband. In contemporary Ghanaian culture, good looks are so much prized that all contemporary music videos and films are flooded with this concept. The films feature good-looking men, most preferably tall and fair who show signs of having stayed in either in Britain or in USA. ${ }^{17}$ These men are often referred to as 'fresh boys'. The concept of "fresh boy" is now so popular in educational institutions, especially those in senior high school and universities. Clearly, such modernity is not in the interest of society. Bragoro's intervention to reverse this terrible growing trend in Ghana cannot be overemphasized.

\section{The role of the woman in Akan marriage}

Akan is an oral culture and therefore has a way of keeping information without writing it down. This might appear obvious but the significant aspect of this, so far as Bragoro is concerned, is that the woman becomes an agency of cultural expression which represents the phenomenology of the married woman. She is a repository of knowledge not only because she carries cultural information in her head but, most importantly, because she acts in resonance with traditional wisdom so far as marriage is concerned. However, the question is: how does she transmit this huge cultural knowledge to the next generation since such knowledge is not written? Again, she is the agent of transmission of this culture; she is the knower and doer of this knowledge. She knows all that the tradition says about who a good wife/mother is and acts them out and so the daughter comes to the world and meets these values via her mother. In fact, Yeboah ${ }^{18}$ associates feminine identity with motherhood. This feminine identity which is circumscribed within the confines of marriage is celebrated through songs in Bragoro and on the second day. During the durbar for the initiates, the women singing nwonkro were heard singing:

\section{Me ba yi}

Me bayi, me ba yi, Me ba yi

Me ba yi, me ba yi, Me ba yi

Ose oni ooo!

Pse oni sbaa wesewa!

\section{My daughter}

My daughter, my daughter, my daughter

My daughter, my daughter, my daughter

She takes after the mother

She takes after the mother, a slender lady, a smart lady

Two qualities are being referred to here: the inner and outer qualities of a woman. The last but one line, "She takes after the mother", celebrates the inner quality of a good woman and the last line, the phrase "a slender lady, a smart lady", praises the outer quality of a woman. First, the fact that the daughter has qualified to be celebrated as an initiate is in itself a huge achievement by the mother. It is believed that it is only a virtuous woman who can bring up a virtuous girl and, in the Akan culture, a girl who passes the virginity test is really virtuous and must be celebrated. This is similar to the Reed Festival in Swaziland where the maidens are celebrated for their virginity. The mother stayed chaste till she married. That is what the young woman to be initiated into adulthood represents. What is left is to be a virtuous wife and that is what the initiate is being introduced to and here every activity counts. It has already been indicated that for performance to be valid, there must be a particular setting, a particular time, a particular set of activities by a particular group of people

\footnotetext{
${ }^{16}$ Babatunde Ahonsi, Fuseini, Kamel., Nai, Dela. et al. Child marriage in Ghana: evidence from a multi-method study. BMC Women's Health 19, (2019): 126.

${ }_{17}$ Music released by 4x4 (artistes from Ghana) entitled Fresh One, released in 2009 by Paradise Entertainment Music Label.

18 Philomena Yeboah, Trials of Motherhood: Amma Darko's portrayal of conflicts in mother-daughter bonds in her novels: Beyond the Horizon, the Housemaid, Faceless and Not without Flowers, PhD thesis submitted to the Kwame Nkrumah University of Science and Technology, Kumasi, 2012.
} 
and so the activities or the event happening when the above song is being sung by the women instructs both the performers and the audience how to interpret the song text. ${ }^{19}$ The event is patterned along with certain cultural meanings and it is only during the Bragoro ceremony when the mother celebrates the virginity of her daughter, that the manner of the song text shows the real meaning of Bragoro During the celebration which the researchers observed, when it got to this song, the whole place was electrified and there was a reason for it. This song text was using special codes that could be interpreted by the participants and so, for the performer and audience alike, there was a collaborative expectancy that made them celebrate not only their identity as a unique group of people but also the woman as being virtuous, which is a pre-requisite for a good wife. The feeling was contagious and everybody was either singing or dancing or both. This was because participants were celebrating a community value that was being transmitted to a younger generation to be carried on to the next generation. By so doing the philosophy of a virtuous Akan woman is transmitted from generation to generation through the Bragoro celebration.

Indeed, after celebrating what the mother stands for, the next song the women sang celebrated the daughter for following the footsteps of her mother:

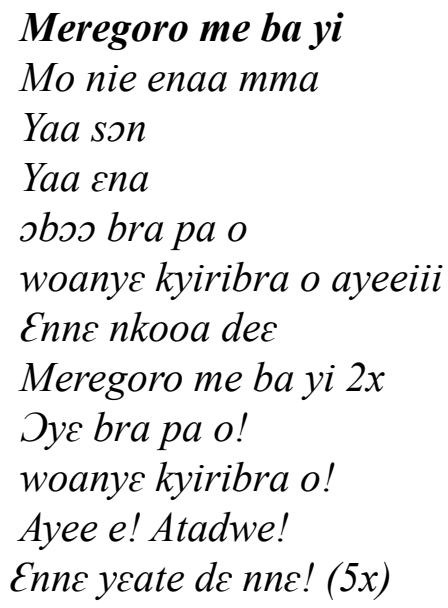

\author{
I am celebrating my daughter \\ Greetings ladies \\ Greetings lady \\ Greetings mother \\ She has stayed pure \\ She did not sleep with a man \\ As for today \\ I am celebrating my daughter \\ She is of good virtue \\ She has not slept with a man before \\ Ayee e! Tiger nuts! \\ We have heard good news today!
}

The women and even the men were simply beside themselves for the good news that the young women, the initiates, had passed the virginity test. The community with one accord was celebrating something more than what the initiates had demonstrated; they were celebrating a philosophy of the community. Various dignitaries were present to celebrate this honourable event. The Regional Minister, Simon Osei Mensah, who hails from the area, was there not just to grace the occasion but to participate in the celebration of this philosophy. The Deputy Minister for Education, Hon. Osei Adutwum was also there to support the celebration of this philosophy. The District Chief Executive, Hon. Lawyer J. K. Asuming was also busy with affairs of the celebration.

The District Chief Executive said in his address that in his tenure as the Assemblyman for the area, he moved for the reintroduction of Bragoro and the Queenmother rallied behind him. He added that the Chief and his elders also supported his idea to curb the rate of teenage pregnancy in the village. That goes to stress the extent to which the celebration is a community affair. The District Assembly offered the three initiates educational scholarships. The Community also gave them an amount of Ghe 300 each as a gift. Family members and friends of the families of the initiates offered the initiates pieces of cloth, jewelry, fowls, sewing machines, handkerchiefs, beads and other gifts. The purpose of the gifts was in recognition of the achievements of the initiates. Also, the symbol of tiger nuts in the text above expresses the joy that such an occasion brings. In the Akan tradition, the tiger nuts and the cola nuts are both chewed but the cola nut is bitter and the tiger nut is sweet. The contrast is to emphasize the sweet nature of the tiger nut. It, therefore, signifies the beauty in virginity which is expressed in fanfare, music, eventful activities, and in the flamboyance of the characters. All these are part of the structures to act out this philosophy. The celebration of Bragoro is also

\footnotetext{
19 Bauman, Verbal Art as Performance.
} 
meant to also teach the young girls who are yet to have their puberty rites, just to ensure that this philosophy is kept alive throughout all generations.

\section{Love}

What is it that binds the man to the woman: love. The song text above, Ama Serwah, is so clear about Akan concept of love: unconditional and only for the married.
Yenfa ah॰fe enware,
We don't marry because of looks,
Yede suban na eware.
We marry because of good character

There is still a proviso here for love and that is a good character. Good character or a well-behaved man is also a function of the family he belongs to and it goes beyond what he is capable or incapable of doing as an individual.

A good husband is supposed to behave in a certain way within the parameters of conjugal love. As an individual, he is supposed to appreciate the delicate nature of the woman. Thus:

\author{
Fa mpadoa behyia me \\ Fa mpadoa behyia me o $/ 2 x$ \\ odo ye wuo ei \\ fa mpaboa behyia me o $2 x$ \\ na me nan yi kyiri abossea
}

\author{
Welcome me with a sandals \\ Welcome me with a sandals \\ Love is sweet \\ Welcome me with sandals \\ Because my feet can't walk on gravels
}

This song was sung when the initiates were being brought back from the riverside, carried on the back of old ladies after the ritual bath. All these activities were heavily laden with cultural inclinations that make the Bragoro song text unique. The initiates were carried on the back of the old ladies because they were considered so delicate that their feet should not be allowed to touch the ground, lest some stones could hurt their feet. The ritual bath was a purification process of being separated from the children and being in the transitional stage to motherhood. Nonetheless, all these have meanings in the Akan culture and no other culture engages in such activities; the Akans are the senders and addressees of such messages with regard to the expectation of the man and the woman within the confines of the Bragoro celebrations. Therefore, the Akans understand that such information is only valid with a prescribed occasion meant for a specific group of people and such a system of communication is "how frames are invoked and shifted." ${ }^{20}$ Framing, according to Bauman $^{21}$ is "a metacommunication which gives the receiver instructions or aids in his attempt to understand the message". In this context, therefore, the song is beckoning the man to gallantry: how to treat a woman, how to pamper a woman and how to make her feel like a queen, all within the Akan cultural interpretation which the text provides. Maame Abena Anima ( an indigene of the town) ${ }^{22}$ showed excitement when she heard this song and so the researchers sought her opinion on this song and this is what she said:

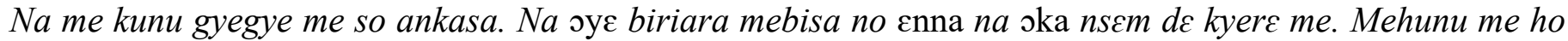


ahycasec no.

\section{Translation}

My husband really pampered me. He would do everything I asked of him and he would say very kind words to me. I really felt like a queen. Today, that treatment is no more there and this occasion brings nostalgic feelings of the early part of my marriage.

Within the context of cultural interpretation of this Akan text, love grows when the condition being described

\footnotetext{
${ }^{20}$ Bauman, Verbal Art as Performance, 15.

21 Bauman, Verbal Art as Performance, 15.

22 Interview with Maame Abena Anima, Worakese, 22 January, 2019.
} 
by Maame Abena Anima prevails. When the woman is thus pampered, she reciprocates the love and this was the aspect expressed in a song during the cto ritual meal session on the second day of the celebration.

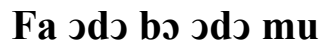

$F a$ s $s$ bo sd $\mathrm{mu}$ oo $/ 2 x$

Jdo ye $f_{\varepsilon}$

$\mathrm{Fa}$ sd o bo sd э ти оо

$\mathrm{Na}$ sd $\mathrm{k} \supset \mathrm{de \varepsilon}\lrcorner d\lrcorner$ wo

\author{
Let's be one in love \\ Let's be one in love \\ Love is beautiful \\ Let's be one in love \\ Love goes where love is
}

The repetition of the vowel sound $/ \mathrm{J} /$ in all the lines is a fluent testimony of the harmony and cohesiveness that occurs when affection is constantly repeated. This clears all trust issues and creates mutual feelings, strengthening the love needed for a happy marriage. No wonder the text above testifies to the fact that, " $J d J$ ye fE", (love is beautiful). Yes, it is only beautiful when the kind of harmony described by the text above exists between the man and the woman. The aspect of mutuality of love is further emphasized in the text when it

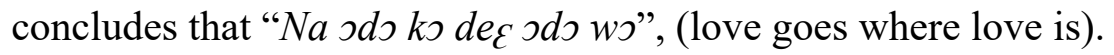

One may say these meanings are universalistic because love is a human value and is experienced in all cultures. This is true but it is equally true that each culture has its own way of expressing it and the Akans in this text are communicating their unique understanding of love and that erotic love is experienced purely as an endogenous phenomenon in marriage. Almost all cultures around the world attach a lot of importance to erotic love in marriage but different cultures have different approaches as to how to ensure that erotic love stays only within the confines of marriage. It is only the Akans who have Kyiribra, the other ritual performed when it is discovered that a girl has slept with a man before her puberty rites. This is an extensive ritual that cannot be treated here but the summary of the ritual is that the girl who fails the virginity test is brought out in the open, libation is poured to pacify the gods and the girl is shaved and made to sit down with the legs stretched forward. A sheep is slaughtered on her lap and the blood is poured on her head, indicating the seriousness of the taboo she has committed. She is then banished from the village. ${ }^{23}$ All these are done in the full glare of the community, including young maidens who are yet to have their puberty rites. The significance here is that engaging in erotic love before puberty rites and, for that matter, before marriage is a serious taboo and therefore talking about love within marriage in the Akan culture occurs within a particular context, a context which does not occur in any other culture.

\section{The Performance of Bragoro}

There are other contexts which contribute to offering the Bragoro song above its unique meaning. The setting, the institutions, the events and the participants in the Bragoro celebration are metacommunicationsthat suggest how to interpret the message. ${ }^{24}$ The setting is a village with a strong traditional worldview. Bragoro in such a place is, therefore, an appeal to tradition because it holds "the past practice as a standard of reference". The village has the traditional leaders as the custodians of the institutions in the culture, thus the participation of the chief and the queen mother impacts strongly on whatever meaning that is being constructed during the festival. ${ }^{25}$ The event of Bragoro is culturally defined and the purpose is not for entertainment but for the sake of community memory and education of the young ones to remain chaste before marriage. As indicated above, the roles are defined by certain social factors and that is why the traditional leaders have their specific roles and the citizens also have theirs. In Worakese, the Queenmother sought the assistance of the political leaders in the district and used her personal resources to resurrect an otherwise moribund culture for the sake of making young girls have moral lives and married people have a happy marriage.

All these are conventions of the Bragoro festival and they frame the meaning of that festival. They provide a special pattern for the performance and the pattern creates a particular genre which is called Bragoro. In other words, one can sing the songs above anywhere but without the full complement of the conventions mentioned above and there is no Bragoro. It is just a drama. This is because these foreign materials fail to

${ }^{23}$ Interview with the Queenmother, Worakese, 22/02/2020.

${ }^{24}$ Bauman, Verbal Art as Performance, 25.

${ }^{25}$ Bauman, Verbal Art as Performance, 25. 
provide the needed metacommunication for the message in Bragoro song texts. Also, it is only when all the conventions, and indeed, Bauman makes it clear that the conventions could be more than what has been listed here, have come together within the above cultural provisions that Bragogo takes place. There is a need to culturally prescribed sites like the riverside, the village foyer; traditional leaders like the chief and the queenmother; participants like the initiates; a culturally prescribed occasion and activity like the sto ritual meal. This is what Bauman refers to as the patterning of performance.

\section{CONCLUSION}

This paper has discussed the Akan concept of sex and marriage. Of course, the concept of sex and marriage differs from culture to culture but for the Akan, sex is exclusively a marital affair and given its orgasmic pleasure, no effort is spared in keeping it away from the entertainment sphere which treats it as just a source of entertainment or a source of gratification. Bragoro song texts are a genre that keys all the meaning of the traditional concept of sex, before and during the marriage within a given setting, activities, places and characters. It is a site where the epistemic of Akan sex and marriage are provided and it does so in the form of celebration, and in the course of the celebration, all the conventions that go to define Akan sex and marriage are made available. The Akan culture abhors pre-marital sex and prescribes specific roles for the man and the woman in marriage. The most arresting aspect of this celebration is the Akan epistemic of love, the element that hooks the man and the woman together in marriage. All these epistemics constitute a philosophy of culture that endures all seasons and are passed on from generation to generation and amid modernity, the Akan remains an Akan so far as sex and marriage are concerned. Of course, this is not to dismiss the fact that in real life, there are Akans who do not do otherwise but the intertextual relationship between the Bragoro song texts and the real world of the Akans provides this philosophy that runs throughout all ages and guides the life of the "modern" Akans in spite of the huge global influence on them. Thus, the Akan will always be an Akan.

\section{ABOUT AUTHOR}

Peter Arthur(PhD) is a Senior lecturer in the Department of English, Faculty of Social Sciences, Kwame Nkrumah University of Science and Technology, Kumasi, Ghana.

Angelina Mensah is an MPhil student in the Department of English, Faculty of Social Sciences, Kwame Nkrumah University of Science and Technology, Kumasi, Ghana.

\section{BIBLIOGRAPHY}

Arthur, Peter. Philosophy and Heroism: The Literary Perspective of Yaw Asare's Ananse in the Land of the Idiot, E-Journal of Humanities, Arts and Social Sciences, Vol. Issue 5, (2020): 152-164.

Ahonsi, Babatunde., Kamil Fuseini, Dela Nai, Erika Goldson, Selina Owusu, Ismail Ndifuna, Icilda Humes and Placide L. Tapsoba. Child marriage in Ghana: Evidence from a multi-method study. 1. BMC Women's Health, 19:126, (2019): 1-15

Barber, Karin. Text and Performance in Africa, Bulletin of SOAS, 66, 3, (2003): 324-333.

Bauman, Richard. Verbal Art as Performance, Illinois: Waveland Press, 1977.

Boyer, Pascal. Tradition as Truth and Communication: A cognitive description of traditional discourse, New York: Cambridge University Press, 1994.

Campbell, Joseph. The Hero with Thousand Faces. California: Joseph Campbell Foundation, 2008.

Echeruo, Michael. The Dramatic Limits of Igbo Ritual. Research in African Literatures, 4(1), (1973): 21-31.

Ghana Statistical Service, "Ghana Facts Sheet," 2021. Accessed, August 8, 2021.

www.statsghana.gov.gh/ghfactsheet.php.

Graham-White, Anthony. Ritual and Drama in Africa. Educational Theatre Journal, 22(4), (1970):339-349.

Goody, Jacques. The Interface between Written and Oral, London: CUP, 1987.

Fasold, Ralph and Connor-Clinton, Jeff. Eds. Introduction to Language and Linguistics, New York: CUP, 2006. 
Hountondji, Pauline. transl. H. Evans \& J. Rée, African Philosophy: Myth and Reality, Bloomington, Indiana: Indiana University Press, 1983.

Hymes, Dell. and Gumperz, John, eds. Direction in Sociolinguistics: Ethnography in Communication, London: Bolt, Rinehart and Winston Inc., 1972.

Racine, Jean. Phedre: Tragédie en cinq actes et en vers, Bourgogne: Libre Theatre, 1677.

Selasi, Taiye. Ghana must Go. New York: Penguin Press, 2013.

Silverstein, Michael. And Urban, Greg. "Natural History of Discourse,"

Silverstein, M. and Urban, G. (eds.) Natural Histories of Discourse, London: University of Chicago Press, (1996):1-20.

Shils, Edward. Tradition. Chicago: University of Chicago Press, 1981.

Smith, Anthony. Nationalism and Modernism: A critical survey of recent theories of nations and nationalism, London: Routledge, 1998.

Tonkin, Elizabeth. Narrating our past: social construction of oral history. New York: Cambridge University Press, 1992.

Urban, Greg. "Entextualization, Replication, and Power". In Silverstein, M. and Urban, G. (eds.) Natural Histories of Discourse, London: University of Chicago Press, (1996): 21-44

Urban, Greg. Metaculture. London: University of Minnesota Press, 2001.

Vansina, Jan. Oral Tradition as History, Nairobi: East African Educational Publishers, 1985.

Wiredu, Kwesi. Philosophy and an African Culture, New York: Cambridge University Press, 1980. 